\title{
Unfinished Business?
}

\section{Faith Communities and Reconciliation}

\section{in a Post-TRC Context}
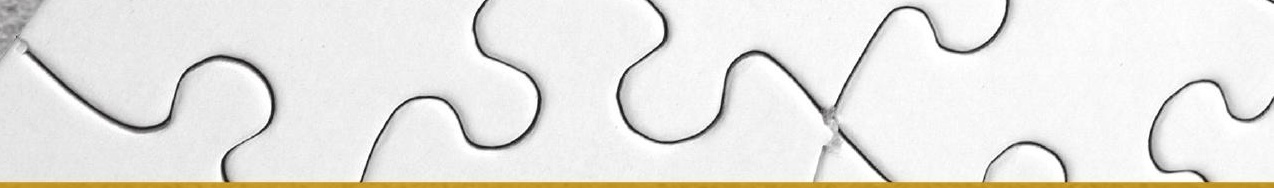


\section{Chronicle of the re-enactment of the TRC's Faith Communities' Hearings with a view to the present and future of a Post-TRC South Africa}

\section{8-9 October 2014, Stellenbosch}

Christo Thesnaar and Len Hansen ${ }^{1}$

\section{Introduction}

On 8 October 2014, the Beyers Naudé Centre for Public Theology in the Faculty of Theology, Stellenbosch University, in collaboration with the Desmond and Leah Tutu Legacy Foundation, hosted the re-enactment (also called a re-enactment consultation) of the Truth and Reconciliation Commissions' (TRC) Faith Communities' Hearings. During the TRC's Faith Communities' Hearing in 1997, different faith communities in South Africa, including Christian churches and some religious organisations, submitted presentations on their role in the apartheid history of our country. They also commented on their commitment to reconciliation and a reconciled future for South Africa. It was no coincidence that the re-enactment coincided with the $20^{\text {th }}$ commemoration of the birth of a democratic South Africa, as at the time, and following it, there was an increase in the divisions and friction

1 Christo Thesnaar is a professor of Practical Theology in the Department of Missiology and Ecclesiology and the Director of the Unit for Peace and Reconciliation of the Beyers Naudé Centre for Public Theology. Len Hansen is an associate professor of Systematic Theology and the Director of Research in the Faculty of Theology at Stellenbosch University. 
I Chronicle of the Re-enactment of the TRC's Faith Communities' Hearings I

within South African society in general and, in particular, on the role that the faith communities play or should play in this regard. Therefore, the re-enactment aimed to find, amid the 20-year celebrations, ways to again put the process of reconciliation back on the main agenda of all faith communities in the country. The re-enactment further attempted to make a significant contribution to reconciliation and national unity in the current South African context. It hoped to contribute to the development of responsible and realistic reconciliation strategies for the faith communities and to offer practical suggestions on how to address the challenges of reconciliation and nation-building at the southern-most tip of our continent.

In telling the story of the re-enactment, the structure of this chronicle will first describe the events leading up to it; next, it will give an overview of the two days of the re-enactment; and, finally, it will end with a general conclusion.

\section{Run-up to the re-enactment}

In the lead up to the $20^{\text {th }}$ anniversary of democracy and the $15^{\text {th }}$ year of the conclusion of the TRC process, it was clear that the drive to reconcile the nation had all but disappeared from the agendas of faith communities, government and civil society. What was not easy to understand, was that this development took place over time and amid growing challenges to transformation, economic justice and land distribution, to name a few, but also an apparent increase in levels and incidences of racism, hatred, violence, frustration and anger. It also subsequently became clear that neither the religious sector, civil society, nor government expressed a fundamental urgency, are willing to or have the capacity to address the original recommendations made by the TRC. Against this backdrop, it was decided to host a small symposium on the challenges of reconciliation in a postTRC South Africa at the Faculty of Theology at Stellenbosch University from 10 to 11 February 2014.

Apart from discussing the decreasing focus on reconciliation, delegates at the symposium were also eager to discuss how to address unresolved trauma, deal with unresolved issues and anxiety from the past, how to promote the so-called healing of memories of both victims and perpetrators and to revisit the commitments made by the churches at the TRC hearing in 1997. In terms of methodology, it was decided not to follow a conference type of symposium where participants would present papers followed by limited time for discussion. We rather asked a few participants to share their understanding of current challenges and then allowed for interactive open sessions with ample time for discussion and deliberations. 
On the first day of the symposium, Dr Fanie du Toit, the then Director of the Institute for Justice and Reconciliation, shared his views on the current state of reconciliation in South African. Dr Deon Snyman, from the Restitution Foundation, did the same based on his engagement with a process of reconciliation in the town of Worcester, in the Western Cape. The key themes raised after constructive discussions and reflections were the following:

1. How does one define reconciliation?

2. What are the conditions needed for effective reconciliation?

3. What is the role of religion in processes of reconciliation?

4. What is the role of the church in reconciliation?

5. What to do regarding generational guilt?

6. How to go about harnessing our social resources, organising courageous conversations, remembering the past, justice, etc.

On the second day, Fr Michael Lapsley, Director of the Institute for the Healing of Memories in Cape Town, shared important perspectives shared on the perspectives from the first day of the symposium. In short, the first day's discussions made clear that the faith communities should play a key role in assisting perpetrators under and beneficiaries of apartheid to deal with their guilt; faith communities should guide the latter on a journey of reconciliation and they (faith communities) should also become advocates for the needs of the victims of apartheid and should be active in the transformation of society. Then delegates from the international community, who also participated, shared their experiences of reconciliation and healing within their contexts, to establish whether South Africans may learn from the processes in their countries. Dr Wilhelm Verwoerd reflected on reconciliation in Northern Ireland (where he worked for several years); Prof Ralf Wüstenberg on reconciliation in a post-unification Germany; and Prof Martin Leiner on both the processes in Germany, but also in post-genocide Rwanda. It was during the conclusion of the symposium in discussing possible ways forward, that the seeds were sown for the organising of a re-enactment of the Faith Communities' Hearings of 1997 and a symposium on war veterans, hosted in March/April 2015.

After some deliberations between Piet Meiring and Christo Thesnaar, it was decided to approach Emeritus Archbishop Desmond Tutu to enquire whether he was willing to support the concept of a re-enactment of the TRC Faith Communities' Hearings. He was overwhelmingly in favour of such a re-enactment consultation and offered the assistance of the Desmond and Leah Tutu Legacy Foundation. The latter also paved the way to approach former commissioners (some of whom were, in fact, present during the Faith Communities' Hearings in 1997) to participate in the reenactment. We were overwhelmed by and extremely grateful for the positive response to our invitation from the former commissioners as well. 
I Chronicle of the Re-enactment of the TRC's Faith Communities' Hearings I

Intending to revisit the past to address the present and to contribute towards building a united future, we invited the faith communities that attended the original TRC hearings in East London. We would offer them an opportunity to revisit their contributions made in 1997. However, we also decided to invite faith communities that did not attend the original hearings, or that could not attend them. We wanted to provide them with the opportunity to contribute to the topic of current challenges facing our country concerning reconciliation. Thus, we requested each faith community to reflect on their contribution during the 1997 hearing and then to prepare a short presentation on their faith community's vision, responsibility and commitment to reconciliation within the current and future South African context. The idea was that, where possible, the person who testified before the commission in 1997 would present their reflection and that a younger member of the community would expand upon their vision, responsibility and commitment towards reconciliation now and in future. Although impossible to reach the latter ideal in all cases, the response from the faith communities to participate was very positive.

\section{The re-enactment consultation}

\section{Structure}

From the outset, we decided to set up the re-enactment in a similar format as the Faith Hearing in 1997, with the seating and the structure arranged accordingly. Tutu chaired the 1997-hearings and would do the same during the re-enactmenthowever, during the re-enactment Tutu also chose to share chairing responsibilities with other (former) commissioners who attended. The commissioners who took part in the re-enactment was Ms Yasmin Sooka, Prof Hlengiwe Mkhize, Ms Glenda Wildschut and Prof Piet Meiring.

Day 1 and the morning of Day 2 consisted of contributions (submissions) by the various faith communities and a submission by the South African Council of Churches (SACC). The afternoon session of Day 2 was reserved for contributions and reflections by local and international participants that did not represent specific South African religious traditions or denominations. The re-enactment concluded with a session on a possible way forward. The section below gives a more detailed picture of the programme of the two days and the different participants. 
The programme

\begin{tabular}{|c|c|}
\hline \multicolumn{2}{|r|}{ DAY 1: WEDNESDAY 8 OCTOBER 2014} \\
\hline 09:00 & $\begin{array}{l}\text { Welcome: Prof Nico Koopman, Dean: Faculty of Theology, } \\
\text { Stellenbosch University }\end{array}$ \\
\hline \multirow[t]{3}{*}{ 09:05 } & Opening and reflection: Archbishop Emeritus Desmond Tutu \\
\hline & $\begin{array}{l}\text { Introducing the panel: Ms Yasmin Sooka, Prof Hlengiwe Mkhize, } \\
\text { Ms Glenda Wildschut and Prof Piet Meiring }\end{array}$ \\
\hline & Submissions by faith communities: Chair: Ms Glenda Wildschut \\
\hline 09:45 & Anglican Church of Southern Africa: Dean Michael Weeder \\
\hline 10:00 & $\begin{array}{l}\text { Methodist Church of Southern Africa: Dr Dion Foster; } \\
\text { Rev Vuyani Nyobole }\end{array}$ \\
\hline $10: 30$ & $\begin{array}{l}\text { Catholic Church: Bishop Kevin Dowling and } \\
\text { Archbishop Jabulani Nxumalo (unable to attend) }\end{array}$ \\
\hline $11: 30$ & $\begin{array}{l}\text { Uniting Presbyterian Church in Southern Africa: Prof Jerry Pillay and Rev } \\
\text { Douglas Bax }\end{array}$ \\
\hline $12: 00$ & $\begin{array}{l}\text { Evangelical Lutheran Church in Southern Africa (ELCSA): } \\
\text { Rev P B Mathe; Bishop Horst Müller (ELCSA-NT); Dr Hanns Lessing (a } \\
\text { short 10-minutes presentation on research on German-South African } \\
\text { church relations) }\end{array}$ \\
\hline $12: 30$ & $\begin{array}{l}\text { Baptist Union of Southern Africa: Rev Angelo Scheepers; } \\
\text { Rev George Ngamlana; Rev Deon Malan }\end{array}$ \\
\hline $14: 00$ & $\begin{array}{l}\text { Dutch Reformed Church in South Africa (Nederduitse Gereformeerde } \\
\text { Kerk, NGK): Rev Freek Swanepoel; Dr Kobus Gerber; } \\
\text { Prof Nelus Niemandt }\end{array}$ \\
\hline $14: 30$ & $\begin{array}{l}\text { Uniting Reformed Church in Southern Africa: Rev Peter Grove and } \\
\text { Prof Mary-Anne Plaatjies van Huffel }\end{array}$ \\
\hline $15: 30$ & $\begin{array}{l}\text { Dutch Reformed Church in Africa (Nederduitsch Hervormde Kerk van } \\
\text { Afrika, NHK): Rev E G Fourie }\end{array}$ \\
\hline $15: 45$ & $\begin{array}{l}\text { Reformed Churches in South Africa (Gereformeerde Kerke in } \\
\text { Suid-Afrika, GKSA): Rev Cassie Aucamp; Prof Amie van Wyk }\end{array}$ \\
\hline $16: 15$ & $\begin{array}{l}\text { The Apostolic Faith Mission of South Africa: Dr Frank Chikane and Pastor } \\
\text { Daniel Andrews }\end{array}$ \\
\hline $16: 45-17: 00$ & Concluding remarks \\
\hline \multicolumn{2}{|r|}{ DAY 2: THURSDAY 9 OCTOBER 2014} \\
\hline \multirow[t]{2}{*}{ 09:15 } & Opening and Reflection: Rev Mpho Tutu \\
\hline & Submissions by faith communities (continued) \\
\hline 09:45 & United Congregational Church of Southern Africa: Rev Thulani Ndlazi \\
\hline
\end{tabular}


I Chronicle of the Re-enactment of the TRC's Faith Communities' Hearings I

\begin{tabular}{|l|l|}
\hline \multicolumn{2}{|c|}{ DAY 2: THURSDAY 9 OCTOBER 2014 (cont.) } \\
\hline 09:30 & $\begin{array}{l}\text { TEASA: Dr Nadine Bowers du Toit (presenting a written submission by Dr } \\
\text { Moss Nthla) }\end{array}$ \\
\hline 09:45 & $\begin{array}{l}\text { South African Council of Churches: Dr Brigalia Bam and } \\
\text { Bishop Malusi Mpumlwana }\end{array}$ \\
\hline 10:15 & $\begin{array}{l}\text { Muslim Community: Mr Thandile Khona (President of the Muslim Youth } \\
\text { Movement of South Africa) and Maulana Abdul Khaliq Allie (Secretary- } \\
\text { General of the Muslim Traditional Council) }\end{array}$ \\
\hline 10:45 & $\begin{array}{l}\text { Hindu Community: Mr Ballen Gangen (South African Tamil Federation) } \\
\text { and Ms Nalini Gangen (Representative of the Maha Sabha) }\end{array}$ \\
\hline 11:45 & $\begin{array}{l}\text { Jewish Community: Mr Leonard Shapiro (South African Jewish Voices for } \\
\text { a Just Peace); Written submission by the } \\
\text { Chief Rabbi Dr Warren Goldstein (to be read) }\end{array}$ \\
\cline { 2 - 3 } & $\begin{array}{l}\text { Comments and Reflections: Prof Jaap Durand; Prof Eddy van der Borght; } \\
\text { Prof Nico Koopman; Dr Rashied Omar and Dr Vicentia Kgabe }\end{array}$ \\
\cline { 2 - 3 } & Discussion: The way forward (facilitated by Dr Frank Chikane) \\
\hline Closing comments: Archbishop Emeritus Desmond Tutu \\
\hline $16: 00$
\end{tabular}

\section{Summary of Day One}

Prof Nico Koopman, on behalf of Stellenbosch University, opened the historical proceedings with prayer and welcomed delegates to the re-enactment. In his prayer, he reminded the participants of the importance of reflecting on our country, calling, past, but also on our future. He expressed the hope that this consultation will advance the hunger for healing and dignity, for reconciling justice, equality and the freedom of all.

Archbishop Tutu then thanked all for their presence and expressed his surprise at the turnout. He reflected on the very challenging context South Africa finds itself in then, given the lack of funding to ensure justice for all and the tasks facing them, both manifold and hard. He reiterated that it is extremely difficult to stand up against one's comrades as they, since elected in positions of power, have also made mistakes, including involvement in corruption, for which they need to be criticised. He concernedly shared that, in his mind's eye, he has an image of God crying - because God sees Syria, Gaza, South Sudan, the Central African Republic; God sees the suffering, the violence, especially the appalling rape statistics of women and children in South African. In conclusion, he expressed the hope that all present at the re-enactment will, over the next two days and in future, look at the world through God's eyes to try to find a way to wipe the tears from God's face. 
Commissioner Glenda Wildschut chaired the first session of the re-enactment and announced that the consultation would start with the submission of the Anglican Church of Southern Africa. In the absence of Archbishop Thabo Makgoba, Dean Michael Weeder, Dean of St George's Cathedral, presented the submission. The initial submission before the TRC in 1997 was done by the then Bishop Michael Nuttall, the Bishop of Natal. Dean Weeder titled his submission, An Endangered Address, derived from a poem by Jeremy Cronin. In the poem, Cronin reflects on a submission made by a former torturer, a Special Branch police officer. In the latter's police officer's submission, he speaks of a fellow that struggled with the reality that he had been party to, namely sending a parcel or letter bomb to a family with whom he had stayed with and the little girl, a child he had known personally, eventually killed in the mission. In the poem, the address where the parcel was sent is called 'an endangered address'. Dean Weeder's submission then reflected on what he called the variety of endangered addresses in our society at that time.

Dean Weeder raised key questions from Nuttall's submission in 1997:

But much more, much more important: What are we going to do for the healing of this land? That is going to be the major challenge. What are we going to do to carry out the ministry of reconciliation that has been entrusted to us?

As he addressed this question, Weeder acknowledged, amongst other things, that the church had not yet developed a 'healthy language', in terms of verbs and adjectives related to race. He pleaded for the church to deconstruct the language of faith in a way that people, who are not necessarily part of regular congregations, will understand. The problem, Weeder indicated, is that we have found comfort in the localised, what the late Albert Luthuli called 'ghetto identities' that will contribute to the making of a greater nation, but that we have since gotten stuck in those identities. The 'Endangered Address', according to him, will cause further impoverishment to occur if you are encountered in your status amongst the poor. Therefore, it remains a challenge, but we need to grapple with our inability as churches to recognise that in the Western Cape one finds a national minority being a regional majority and the poor are found in great numbers in that demographic. We must find a way to sustainably deal with key issues in these communities, such as gangsterism in Mannenburg or vigilante attacks in Khayelitsha.

Dean Weeder concluded his submission by emphasising that the church needs to find a way to engage business and encourage them, not just for their own sake, but also in the interest of the community, to reinvest in a much more patriotic act, 
I Chronicle of the Re-enactment of the TRC's Faith Communities' Hearings I

in the youth, in women and other most vulnerable groups in society. Not for the sake of maximum profit and gains, but for the sake of a better quality of life for all South Africans.

The Methodist Church of Southern Africa was the second faith community to make their submission at the re-enactment. Rev Vuyani Nyobole and Dr Dion Foster represented Bishop Ziphozihle Siwa, who was unable to attend. The original Methodist submission, in 1997, was made by Rev H. Mvume Dandala.

Nyobole began his submission with a quote from the 1997-submission that referred to a confession the church made in 1960:

The Methodist Church of Southern Africa recognises that Christian people and groups, whilst responsible for contributing towards the solution of the problems of humanity in interpreting the mind of Christ in the situation of South Africa, they themselves are deeply involved in those problems. We as a church confess that many of our own members are guilty of race prejudice and are prone to the very sins that we regard as our duty to condemn.

Nyobole concluded his reference to the 1997-submission by stating that this was true for the past but also remained true for today: That we find it is easy to make those confessions and statements but find it difficult to live up to them. In this regard, he referred to the shortcomings of the act that established the TRC. He emphasised that it was a compromise negotiated via the Codesa process and, as such, it mostly favoured the perpetrators more than the victims. The point Nyobole wanted to make was that amnesty was immediately awarded to the perpetrators, while victims still awaited reparation. Commissioner Yasmin Sooka affirmed this when she commented on the submission of Nyobole by saying that she was struck, as was the victims group Khulumani, a few months ago when the churches requested government to release Clive Derby-Lewis (found guilty of the murder of Chris Hani) and that they should release Eugene de Kock (former Vlakplaas operative) from prison. In their reaction to the call by the churches, Khulumani stated that they had not heard a similar request from the church leaders to government regarding the fact that reparations remain an outstanding issue. Nineteen years down the line, according to Sooka, the President's Fund is still sitting on a huge amount of money, while community reparations have not been paid and while the pardon process has constantly been used as an attempt to grant more amnesties and it is left to victims or survivors to oppose this state of affairs. Sooka confessed that, whenever reference is made to the prophetic voice of the church, she always asks herself, why the churches remain silent on the issue of reparation. 
Nyobole also regretted that the statute establishing the TRC placed more emphasis on truth than on reconciliation. He indicated that the vision of the Methodist Church of Southern Africa was to make every local church a centre of healing and transformation and that churches should also strive towards having their pastors, their clergy act as agents of that healing and transformation within their local contexts. This vision, however, remains a challenge and cannot be imposed on the clergy. Thirdly, Nyobole indicated that, up to then, faith communities have not clearly defined their new, post-apartheid roles in relation to government, leading to a paucity within faith communities of critical theological reflection on their role and responsibilities - also a paucity of collective critical theological reflection. To him, the implication of this paucity is the moral decay people experience in our society. Nyobole for the most part blamed churches for this, since those who are corrupt in government are also (often) church members, sitting in church pews! However, the problem is that churches seem not to have reached out to them to hold them accountable.

In support of the comments made by Nyobole in his submission, Dr Dion Foster made a significant point by stating that the church has lost touch with a people's theology; that churches and faith communities have forgotten that they represent the people of this nation who remain largely impoverished and disenfranchised. Foster also emphasised the critical importance of interfaith and ecumenical cooperation as well as churches and faith communities' recognition of their culpability for what is happening in our country and amongst its people. What this entails, Forster said, is that the church has to bear responsibility for the fact that our teaching and our discipleship, our witness and our work, have not been consistent with the values that we hold.

The Roman Catholic Church (RCC) was the third faith community to make its submission. Bishop Kevin Dowling did so in the absence of Archbishop Jabulani Nxumalo. Dowling, together with Archbishop Buti Tlhagale (who was unable to attend) also represented the RCC at the 1997 Faith Hearings. In a powerful submission, Downing not only talked about taking responsibility for the past but also offered guidelines to address current challenges. He started his submission by referring to the 'ambivalence' and 'complexity' of the Roman Catholic community of South Africa in terms of its response to apartheid atrocities by indicating that, for example, both Chris Hani and Janusz Waluś (the person that gunned Hani down) was and is part of that community. He referred to the years that the Catholic community was a missionary community, particularly in terms of its leadership. The church was inwardly focused, but also became increasingly challenged by the 
I Chronicle of the Re-enactment of the TRC's Faith Communities' Hearings I

fact that the vast majority, 85 per cent of its members, were from the oppressed majority. Dowling referred to the theology of, for example, Albert Nolan that played a major role in the way the church became aware of the challenges faced by many people in our country.

In his submission, Dowling also referred to statements made by the church that did not necessarily reflect a conversion process, particularly in the privileged minority of the church - something he believes remained a problem. He is, therefore, convinced that unless the privileged minority in this country undergoes a conversion process, personally and as a community, it will be impossible for them to be on the same page as those experiencing daily injustices. If we are not able to sit down and take the hand of someone who has HIV and Aids, the landless, the poor and those whose human rights are abused, the vulnerable (children and women), we will not be able to make a difference.

Dowling also felt very strongly that South Africa needs transitional justice, but that the starting point toward this should always be from the experience of the victims and survivors. The transitional justice process has to include the recovery of the truth and the issue of economic transformation and restitution. He said this against the background that he firmly believes that not only the victims of human right atrocities, but also the victims of apartheid, and the millions of poor that we have in our country was sold short. In this regard, Downing stated that the church may continue to make statements, but that its real future role will be at the grassroots level where it has to walk with the people so that they can become the agents of their transformation. He said that this is the role he hopes churches continue to play in all communities. Concerning this role and the question of who will then take us forward, Dowling affirmed that only the empowered poor, disenfranchised and violated can take us forward. It is with them that churches and faith communities are uniquely called to be not in isolated ivory towers, but sitting in the shacks of the poor. It is also here where theology needs to be done and where people should be enabled to, once again, believe in their dignity. It is enabling people through our programmes on the ground, however long they take, that churches are going to change the current situation so many still find themselves in.

Downing further emphasised that we can no longer hold on to the perception that 'government must be seen to be doing everything' because government cannot do everything. Faith communities, NGOs and big business must take co-responsibility for the task ahead of us all. He did, however, propose that the government play a leadership role in this regard. But, faith communities have to challenge the government to move away from political opportunism around election time, 
have to come together with the communities, with the activists, with the skills that are available in NGOs and faith communities and should consciously commit to a social compact to deal with these critical issues. Dowling identified several critical issues, in line with those already highlighted during the re-enactment, such as migration from our rural villages to the cities and people ending up in the appalling shack settlements, jobless and hopeless, often the targets of xenophobia and, above all, the unacceptable rate of unemployment among the youth. In terms of redistributive justice, Dowling reminded those present, that the biggest beneficiaries of this remains the business community and mentions a proposal to the government of a special tax on the business community that may be allocated to development programmes. Government, however, did not take this up and so we are still all complicit in this regard.

The United Presbyterian Church of Southern Africa (UPCSA) was the fourth faith community to present its submission, led by Prof Jerry Pillay and accompanied by Rev Douglas Bax. Bax was one of the persons who made the UPCSA submission before the TRC in 1997. He started his submission with reference to the Reformed Presbyterian Church and the Presbyterian Church of South Africa that were united in 1999 to become known as the UPCSA. For this reason, at the TRC Faith Communities' Hearings in 1997, there was not one submission as now, but two one from the Presbyterian Church of South Africa and one from the predominatelyblack Reformed Presbyterian Church. Dr Gideon Khabela made the submission to the TRC on behalf of the latter.

Bax also referred to statements they made as a church over the years against apartheid and issues such as conscientious objection, which caused internal dissent in the church, even leading to some congregations breaking away from the church. Bax spoke about unequal stipends in the Presbyterian Church; something that has never been the same and a still unresolved issue. Referring to 1973, he remembered the little confession of faith, a liturgical confession against apartheid and against the prevalent pietism that separated the gospel from politics. He also mentioned that, in 1975, in the process of preparing for a conference of churches organised by the World Alliance of Reformed Churches - then still including the NGK - the Presbyterian Church produced and adopted a document later called, A Different Gospel, that analysed and repudiated the exegetical basis of the theological justification and rationalisation of apartheid. Bax paid tribute to the work done by Rob Robertson, a minister in the church, as it is due to his efforts that the Presbyterian Assembly adopted several resolutions in 1981 that were nonviolent active resistance, instead of just statements. These resolutions included 
I Chronicle of the Re-enactment of the TRC's Faith Communities' Hearings I

defying the government by, for example, quoting from banned literature, defying the Group Areas Act by housing ministers in their congregations even if they were of another race and not allowed in the area; and most importantly, defying the Mixed Marriages Act. The church also consistently backed conscientious objectors and called for allowing conscientious objection. The church also refused to serve on the Chaplains' Board and refused to serve on the Board that adjudicated on the treatment of conscientious objectors.

Bax stated the reasons why the church unified - it was what God wanted and both biblically and theologically justified; it was also due to the political situation, the economic situation and the need for reconciliation in the country. Pillay then addressed the question: "So, what have been some of our contributions to the reconciliation processes in South Africa as the UPCSA?"

In his reflection on this question Pillay said, firstly, that the UPCSA focused on the aspect of being a reconciled community, the need for reconciliation and healing, and the reason why the UPCSA mission priorities are 'health', 'wellbeing' and 'securing justice'. UPCSA realised that health and wellbeing are often affected by injustices, oppression and abuse, and, therefore, it committed itself to address injustice, such as economic and gender injustice. He affirmed that there could be no reconciliation without justice. He was also the first person who, in his submission, emphasised the challenge of gender injustice and questioned the lack of women representation in the leadership of the faith communities present. For this, Commissioner Sooka thanked him. Pillay also emphasised that, as a church, they had to face the issue of culture and had to find ways to address what it means to be a human being.

Secondly, Pillay, indicated that the UPCSA see the need for reconciliation and unity on three levels. First, they have to deal with apartheid, colonialism and all the related evils and bring white and black folk together. That still has to happen in many congregations as the need for practical ways to engage reconciliation and healing has been swept under the carpet and, therefore, the hurts of the past still have to be dealt with in many places.

At a second level, there exists a need for internal reconciliation within the UPCSA, and church structures still need redress. The third emphasises that redress will require empowerment and capacitating the church's leaders to exercise leadership in ways that are needed now - for example towards redistributing economic resources of the church to local churches and presbyteries and working towards cross-cultural mission and ministry. To do this, Pillay acknowledged that their church needed training. 
The Evangelical Lutheran Church in Southern Africa (ELCSA), ELCSA-NT and ELCSA Cape were the fifth faith community to present a submission. These three churches were not present at the TRC Faith Communities' Hearings in 1997 and, at the re-enactment, they presented separate submissions as they were not yet united in South Africa. Rev PB Mathe represented ELCSA (as the General-Secretary of ELCSA and on behalf of the presiding bishop, Rev Dr Ndanganeni Phaswana, who was abroad at the time). Bishop Horst Muller represented ELCSA-NT, and Bishop Gilbert Filter represented ELCSA Cape. In his submission, Mathe referred to the importance of Article 16 of the Augsburg Confession, part of the confessional basis of the Evangelical Lutheran Church worldwide. Article 16 addresses the issue of the role of Christians in civil affairs and the fact that the church formed part of the ecumenical community in the fight against the apartheid system. Mathe stated that, in terms of the current context, we would need to challenge the three Lutheran churches to come closer together and, in this process, they need to face the issues of properties, ownership of buildings and other issues that still separate them. Mathe further emphasised the challenge of education and indicated that, although they have lost almost all their schools and hospitals at the hand of government, the church should seriously look at education at school and university level. On a practical level, Mathe referred to a programme, Lutheran Action against Gender-based violence, in which the ELCSA-NT participated. He expressed the hope that the rest of the Lutheran family of churches will participate in this programme as well. The church also started training for informal traders on micro MPA - an entrepreneurship programme on how to expand one's work on the ground and start nutritional gardens. Mathe concluded his submission by stating that the church needs to develop people to their full ability.

Muller (ELCSA-NT) started his submission with an explanation that they represent the hope and the failure of South Africa, as they represent three churches - ELCSA, ELCSA-NT and ELCSA Cape that, for 30 years, have been engaged in attempts at unification, still unsuccessful. Muller and Filter then read from a statement they made in 1997:

We are aware that we have failed to live according to our own basic theological principle, which is our understanding of the Gospel of Jesus Christ, which is the gift of his unconditional forgiving and suffering acceptance. But accepting and enjoying the privileges of the apartheid era ourselves, as members of the white society, and failing to speak out sufficiently against the exploitation and suffering of the majority of the black community, we have hurt many people, not only in their God-given dignity but also in their capability to cope with their daily lives. Yes, by doing so, we have betrayed and denied God's unconditional love of all people, irrespective of race, class, 
I Chronicle of the Re-enactment of the TRC's Faith Communities' Hearings I

culture, education, achievement, gender or creed. We also realise that in contrast to Martin Luther, the initiator of our tradition, we have failed as a church to speak out critically and boldly against overt public injustice and the abuse of power, such as the forced removal of communities from their traditional homes; job reservation; the denial of citizenship; rights to blacks in the country of their birth; police brutality; the break-up of families due to race classifications; vast disparities in education opportunities between black and whites or other policies which affected and hurt the human dignity. We are aware that both as church and individual members we were deeply implicated in injustice of the apartheid era as a whole and wish to put our acknowledgement and sincere regret of this fact on record.

Muller then continued to talk about what has happened since the above statement. He referred to the disappointing challenges in our society, such as increasing corruption, deteriorating infrastructure, soaring crime statistics (especially violent crimes that go unpunished) and the failure of the education and health systems. He emphasised that churches are silent on these issues, but cannot address them on their own. The bishop indicated that the legacy of the old system was that it was legalised injustice and that, although not legalised (due to our wonderful constitution), a lot of tolerated injustice remains. He, therefore, appealed to churches, positioned at the grassroots level, to start building bridges between South Africans and addressing these challenges. To him, this also meant that churches should participate in training their members in what democracy is all about.

Mathe indicated that they had addressed the land issue in their church by donating 95 per cent church-owned land back to communities. Muller, in turn, reiterated the role faith communities might play in equipping those who care for pre-school children daily so that these children should by the time they enter the school have a solid foundation.

The Baptist Union of Southern Africa was the sixth faith community to present a submission, done by Rev Angelo Scheepers (General-Secretary) and Rev George Ngamlana. As a union of churches, the Baptist Union initially appeared before the TRC on the 26 June 1997. Ngamlana said after their appearance before the TRC; they went back as a union to start to deal with the 'elephants in their room'. They have journeyed far on issues such as language and theology and now have their first non-white general-secretary.

Scheepers indicated that he is happy to report that in 2001 the five separate church bodies came together, reconciled their differences and apologised to each other. They committed themselves to work together as one alliance, resulting in the 
formation of the South African Baptist Alliance. He said that during this event, the President of the Baptist World Alliance addressed them and spoke on reconciliation. Except for the Northern region, the other six regions and at a national level, they have witnessed a transformation in leadership. The leadership of almost every one of the Alliance's regions is now fully multicultural, and it is wonderful to see the different cultures working together for the extension of the Kingdom.

Scheepers also told of a special communion service organised by the Alliance in Port Elizabeth to create a space for people from different cultures to apologise to one another and to confess wrongdoing to one another. This event culminated in a Prayer of Confession and Repentance and the making of peace within the different cultures of the Union. However, he also indicated some challenges remained regarding the integration of cultures in the local churches, especially in the Afrikaans churches, the cross-pollination of pastorates and the economic struggles of churches in poor communities. He reported that they have managed to address the challenges facing poor churches by asking the financially stronger churches to assist and help facilitate the development of the economically challenged churches, resulting in at least 40 per cent (86) of the latter churches currently being continually assisted. Scheepers also indicated that the church has other very effective ministries that make a difference in society: the Deeds of Love (a compassionate ministry to orphans and vulnerable children); Living Hope Ministry (a huge frail and an Aids care centre); Living Way (a skills centre in Fish Hoek); a prison ministry in Pollsmoor and God's Mission, our Compassion (a ministry focusing on the alleviation of poverty).

Ngamlana indicated that they are continuously dealing with basic Baptist principles, in terms of the difference between State and Church, not an easy reality to address. Scheepers added that they do believe with all their heart that the Church needs to have a prophetic critique on State and society, and it needs to engage the State where it is out of line. He indicated that he used to attend regular meetings between the Church and the State organised by the president's office during the time of President Mandela and President Mbeki, but the current president has unfortunately stopped this. Ngamlana told the consultation that they spend a whole day dealing with the race issue in their church and that it was probably the most important day in their history as people were completely honest during this process.

The NGK was the seventh faith community to make a submission, as in 1997, done by Rev Freek Swanepoel. Prof Nelus Niemandt, the Moderator of the NGK at that time focussed on their journey post-1997. Rev Kobus Gerber, the General-Secretary 
I Chronicle of the Re-enactment of the TRC's Faith Communities' Hearings I

of the NGK, assisted him in telling this story. Swanepoel began his submission by posing the following question: Did the TRC need the NGK, or did the NGK need the TRC? According to Swanepoel, the NGK needed the TRC as it needed reconciliation. Niemand, in his submission, would affirm this. Swanepoel remembered how they went to East London to confess and say to churches and faith communities: "We are sorry." They needed to do this publicly, and they appealed to the other faith communities and churches to teach and trust them. They wanted to be part of the solution - they wanted to change. The NGK came to East London to say that they wanted to be servants after the example of our Lord Jesus Christ and to ask for the acceptance of the other faith communities.

In his submission, Niemand acknowledged the leadership role of Swanepoel that opened a new avenue in the NGK when he (Swanepoel) participated in the TRC hearing in 1997 and admitted their complicity in the history of apartheid. This admission helped the NGK to experience that truth indeed brings new freedom. Niemand reflected on how Tutu approached the NGK after they made their submission in 1997. To him, this is a case study of how truth can bring reconciliation and an important turning point in the ecumenical re-establishment of the NGK as it started a journey back to the broader ecumenical society within South Africa and, indeed, globally. Niemand, however, also admitted that the process that started with the TRC submission in 1997 was painful since it required of the NGK to acknowledge deep and fundamental theological mistakes it had made in the past, requiring a kind of kenotic self-offering, but one that was experienced as a new journey toward healing for the NGK. It also resulted in a series of decisions and declarations during the years that followed. In 1998, for example, the General Synod officially rejected apartheid; in 2002, it drafted a Declaration of Commitment to Southern Africa and Africa, with explicit focus on healing and reconciliation; in 2004, the General Synod expressed itself positively in terms of the new Constitutional democracy in South Africa; and, in 2007, the NGK issued a declaration of committed to the new democratic South Africa.

Prof Niemand referred to the role the NGK currently plays via its network of formal service organisations under the various synods. He stated that only about 10 to 20 per cent of the beneficiaries of these services are in fact members of the NGK. He further expressed concern about social cohesion; growing racial tension; crime; corruption (the misuse of the riches of the country and public funds) and growing poverty. Niemandt commented that, in terms of economic justice, it is important to re-imagine a new economic system, one where churches can offer something very different from the ugly face of capitalism, but also something different from 
the problems associated with socialism. Niemandt confessed that perhaps the NGK took itself, as a church, too seriously, thereby not taking communities and the context serious enough. He also stated that it is with deep regret that in one of the most important tests of the transformation of our church we have yet again failed and continued to fail, namely the search for unity among the Uniting Reformed Church of Southern Africa (URCSA), RCA and NGK.

Sooka, in her response to the submission of the NGK, asked a very pertinent question: How do we build a sense of accountability amongst the broader beneficiary community? Kobus Gerber responded that the NGK do not see themselves as a European church; it is here to stay and is committed to justice. As a member of the World Communion of Reformed Churches, the NGK, for example, adheres to the Accra Declaration committing itself to the struggle for economic and environmental justice, fighting the empires that oppose this. The NGK, according to Gerber, will play a facilitating and prophetic role to help make South Africa work for the sake of Him who put it (the NGK) here to be with other churches a witness and a light to our continent, Africa.

URCSA was the eighth faith community to make its submission. Rev James Buys, who presented the submission to the TRC in 1997, has sadly passed away and, therefore, Rev Peter Grove, and the moderator of the General Synod, Dr Mary-Anne Plaatjies van Huffel made the submission at the re-enactment. Grove started his submission with a critical remark about repeating the 1997 TRC faith hearing as he believed it would not necessarily help us towards deeper reconciliation. He then continued to highlight four specific points in his submission. The first point was that we live our lives between the tension of memory and expectation between the past and future. Both are highly contested categories, but we make a fundamental mistake if we only look toward the future and forget the past. In the 1997-submission of URCSA, an attempt was therefore made not to read the past in binary and discrete categories, as the past is ambiguous. According to Grove, this ambivalence relates to the compromises made by the oppressed - sometimes to survive, sometimes for self-advancement. Some among the compromised ones of yesterday become the leaders of today. The past was ambiguous and, therefore, we need to recognise that we may re-interpret what we see and, perhaps, even see alternative possibilities. Grove believes that many of the atrocities and violations of the past remain very real and, therefore, cannot just be forgotten.

Secondly, Grove indicated that the churches and faith communities all carry the marks of its broken and sinful contexts, the reason why URCSA only slowly emerged as a non-racial church and continues to struggle in its efforts to find a greater 
I Chronicle of the Re-enactment of the TRC's Faith Communities' Hearings I

Gospel expression with its white counterpart. Grove appealed for the embodiment of what a Godly community should be (according to that community's confessional traditions) as it will go a long way towards enhancing reconciliation. He also indicated that within their church (URCSA), the sad reality is that they still do not cross all the divides within itself. We prefer to stay in our familiar, safe spaces.

Thirdly, Grove affirmed the importance of the acceptance of the Confession of Belhar - the product of the work of both black and white theologians - for the unification efforts of the four sister churches in the Reformed family of which URCSA is part. Embodying this Confession will allow differences to serve a true unity; it will be a sign of embracing the reconciliation wrought already by Christ; and, therefore, ultimately will help these faith communities to grow into a new identity. According to Grove, Belhar argues for downward mobility towards the poor; to stand where God stands; and, in the process, to save ourselves against the pursuit of riches by the white and black elite through systematic material accumulation and the progressive denial of the deprivations of the poor. Therefore, the religious community needs to regard the poor as a higher priority.

Grove's last point was that a vision for a new society that should inform policy and strategy is largely absent today. Thus we need people that truly have the resources to come together to state what we want, without excluding anybody, also entailing a need to adopt the hurts and pain of others. We need symbolic acts of reconciliation, in particular acts of remembrance of those who lost their lives in the struggle.

In her submission, the moderator, Dr Mary-Anne Plaatjies van Huffel, provided the consultation with some background on URCSA and confessed that it is still struggling to re-unite racially segregated churches, specifically the NGK, the NHK, the RCA and URCSA. However, Plaatjies van Huffel also indicated that, despite these difficulties, something beautiful happened in 2012 and 2013 when the NGK and URCSA at their respective synods approved a road map and a memorandum of understanding toward unification. She also applauded the facilitation in this process by Prof Jerry Pillay, on behalf of the World Communion of Reformed Churches. Echoing other church leaders that spoke before her, Plaatjies van Huffel referred to the value of the Religious Leader's Forum that regularly met during the time of President Mandela and President Mbeki. The Forum was committed to the construction of the new values in the society.

In terms of restoration, Plaatjies van Huffel reported on the utilisation of skills and resources to provide trained leadership to disadvantaged communities across South Africa via joint programmes of URCSA and the NGK in several communities. 
For her, it is an absolute necessity that such sharing of resources should occur. She also referred to and supported the call by the TRC for a land audit and, in her reference to the court cases between the URCSA and the NHK regarding property ownership, she acknowledged the impact it had on the church and stated the need to further the reconciliation between these two churches. Plaatjies van Huffel further indicated that a General Fund had been established in URCSA for victims of apartheid, but this also proves to be a tiresome and difficult process. It seems that the congregations, even Synods and people at large are clinging to their resources, their land, their capital, and their social capital and human resources. Plaatjies van Huffel also referred to the commitment of the URCSA to the interreligious process as they approved the Charter of Religious Freedoms and that this Charter is helping URCSA to evaluate its concern about how to go about embracing people from different religious groupings.

Finally, Plaatjies van Huffel referred to challenges that URCSA still faces about language differences among its members; challenges in terms of addressing the gender imbalances for which the church is in the process of drafting and approving a gender policy; and the need to take up discussions about wealth tax and on the issue of eco-justice.

For many delegates, the submission by the Reformed Church of Africa (Nederduitse Hervormde Kerk - NHK), the ninth submission, represented one of the most poignant moments during the re-enactment. The NHK did not make a submission to the TRC in 1997. Rev Fourie of the NHK, however, presented a personal submission, expressing his disappointment that his church did not send him in an official capacity. With this reality in mind, Fourie indicated that he wished to present the NHK as a case study to affirm why the work of the TRC is still vital for faith communities years after the hearing was concluded. He, then, referred to a pastoral letter the NHK issued in 1973 that gave an extensive explanation of why the NHK decided to maintain a membership restricted to white people only (Article 3). He quoted from the pastoral letter where the NHK states that it "rejects any form of integration between church and state". Fourie then stopped, admitting how painful it was for him to read the following from the statement, namely that "[a]partheid has been described as the only honest and Christian policy that would prevent the domination by one group by another ..." The pastoral letter further stated that "the church wishes to state emphatically that these measures" - i.e. segregation within Church and State - "are not temporary, but are permanent and unchangeable and founded on scriptural principles". These general principles are in short, the following: 


\section{Chronicle of the Re-enactment of the TRC's Faith Communities' Hearings I}

- The existence of different nations is part of God's creation.

- The development of the Afrikaner nation in Africa is part of Divine Providence.

- The policy of segregation protects not only white people but also black people from domination and exploitation.

Based on its theological support of apartheid, the World Alliance of Reformed Churches suspended the membership of the NHK (together with that of the NGK) in 1982. In 1990, another pastoral letter was issued by the church; with different wording and a movement towards change. "The church rejects as incompatible with Christian responsibility, any humiliating measures or acts between people, as well as over-emphasis of honour and dignity and respect at the expense of the happiness and prosperity of other people." In 2001, at the NHK General Assembly, another shift came with the following decision taken:

The NHK calls for a confession of guilt before God and fellow man to new life where the love of God determines our conduct towards all people. This, the General Assembly is deeply aware of our church's sin - sin to its fullest, terrifying extent as the Bible depicts it: hate, animosity, rebellion, lovelessness, disobedience and negligence towards God and fellow man. The church, therefore, calls upon all functionaries and members of the church, but also on all the other churches and people to sincerely confess their guilt before God and towards each other continually in public worship and in our personal lives for everything that was wrong in the eyes of the Lord and in our eyes. This confession of guilt must be supported by a new life without any animosity or hate.

In his reflection on this letter, Fourie indicated that the problem with this decision was that this decision only addressed the implementation of apartheid and the acts supported by apartheid. It did not address the NHK's underlying support of apartheid on theological and biblical grounds. It also did not refer the NHK's view that different races are fundamentally irreconcilable. In 2004, Fourie indicated, he had the privilege to be part of a delegation to the WARC, meeting in Accra, Ghana, where the NHK started putting out feelers to ascertain what was needed for the status confessionis, declared by the WARC in 1982, to be lifted and for the NHK to be readmitted to this body. Three conditions were set in 1982: Firstly that black Christians should no longer be excluded from church services, especially from Holy Communion; secondly, that concrete support in word and deed must be given to those who suffered under the system of apartheid; and thirdly that an unequivocal Synod resolution that rejects apartheid in the sphere of church and politics be made. In 2005, 2006 and 2007 NHK delegates met with the WARC and could show that the first two conditions have been met. The article restricting membership was removed from the NHK Church Order in 1999. In 2010, the following resolution was tabled at the General Assembly: 
The Sixty-Ninth General Assembly pronounces unequivocally that it was wrong to defend a certain government policy - apartheid; that apartheid cannot be theologically justified. The church rejects the approval of apartheid because it is contrary to the gospel of Jesus Christ; is based on idea mutual irreconcilability; defends injustice; harms the image of God in human beings.

The Synod put the resolution to the vote. Fourie was in charge of the electronic voting process and was the first person to see the result. He told the consultation how, when the result of the vote came up on his screen, he burst into tears and could not stop crying. The chair had to ask him three times for the result. The result was 57 per cent to 43 per cent in favour of the resolution. Then chaos ensued in the Synod meeting. About 100 delegates from the dissenting group stood up and formed a group calling themselves 'Die Steeds Hervormdes' [The Still Reformed].

In the wake of the above decision, the NHK then declared that the political policy of apartheid put into practice in South Africa, could not be theologically justified and recalled all the church's past approvals of the policy. "It was contrary to the Gospel of Jesus Christ," accepted by 30-70 per cent of delegates and led to a schism in the church. Where the NHK found itself at that moment, Fourie explained is why he wanted to put the NHK before the consultation as a case study of why reconciliation is still necessary. He said the NHK, when it comes to the 'school of reconciliation', was in a different class from many others. He referred to it as a 'special needs class'. These needs included:

- For its past, for pronouncements it made in the past, it has a special need for forgiveness.

- For the delicate times it finds itself in, it has a special need of understanding.

- For the difficult times that lie ahead, it has a special need of support.

- For the challenges, the opportunities that lie ahead for it - also being a church of Africa, the Nederduitse Hervormde Kerk of Africa - it is also moving nowhere, it wishes to remain in Africa. For the challenges that lie ahead, it has a special need for an embrace.

Fourie ended his submission with a plea: "Please embrace my church on the way forward. We are late bloomers. We need your support." At this moment and upon this appeal, all at the consultation stood up and some of the church leaders of mainly black churches, including Tutu, went forward to embrace Fourie as a sign of their commitment to respond to his plea.

The GKSA was the tenth faith community to make their submission. Like the NHK, the GKSA did not make a submission to the TRC in 1997. However, a group of theologians presented the TRC with a confession. Prof Amie van Wyk (one of the authors of the confession) made the GKSA submission at the consultation 


\section{Chronicle of the Re-enactment of the TRC's Faith Communities' Hearings I}

together with Rev Cassie Aucamp. Van Wyk started his submission by stating that it was in Stellenbosch where he wrote the first draft of a confession of guilt during a meeting of the International Reformed Theological Institute in June 1997. This draft was finalised by four academics: himself with Proffs Ponte Venter, Bennie van der Walt and Rev Alwyn Du Plessis from Potchefstroom. Van Wyk proceeded to read from the confession, stating that he believes a confession of guilt never loses its relevancy:

1. The undersigned hereby make a public confession of guilt regarding their share in and neglect with regard to apartheid. The dictates of their conscience have urged them more and more to do this.

2. We hereby confess before God and our neighbour that we have failed in word and action, in church and society, privately and publicly, to testify adequately and unambiguously against the embodiment and execution of the ideology of apartheid, which had an invidious and even ruinous effect on lives of so many of our fellow believers and fellow citizens. With Daniel, we confess in the sight of the Lord, that we have sinned and done wrong; we have been wicked and rebelled; we have turned away from your commands and laws.

3. We confess that we were not courageous enough to testify that we did not pray faithfully enough; did not believe actively enough; did not love fervently enough; did not have enough empathy in the situation of individual and social injustice in which our country was plunged for four decades and more. We acknowledge in great humility that we were guilty of the violation of fundamental human rights. And we acknowledge that we have a share in the directionless movement of our country during times of crisis.

4. We confess that we are deeply guilty in the sight of God and our fellow man [sic] and that this gross neglect and reluctance on our part can only be removed by mercy, forgiveness and reconciliation.

5. We seek forgiveness from God in the redemptive sacrifice of Jesus Christ, but we also plead forgiveness from our deprived and wronged fellow believers and fellow citizens for what we did to them. From our side we undertake, as far as humanly possible, to make amends in word and action for the injury which we did to them through the unfair, discriminatory system.

In the second part of the confession, Van Wyk explained, the motivation and the reasons for the confession are given: "With this confession of guilt an attempt is made to serve the cause of the Kingdom of God ..." Van Wyk emphasised that the authors of the confession of guilt were convinced that it would encourage forgiveness and would promote reconciliation. It would contribute, therefore, to personal, ecclesial and social healing. According to him, what is needed is hopeful people in all possibilities and difficulties that seek the reality of the coming Kingdom of God - that is, after all, a kingdom of joy, peace, freedom and justice.

Aucamp said that Christian hope stretches itself out toward the future. However, it also requires a true and sound evaluation of the past and the present. An 
evaluation is needed that recognises mistakes and wrongs, but it also requires open eyes and thankful appreciation for what God has already accomplished in our lives and the lives of the people of our country. Aucamp made a second point indicating that twenty years ago, the danger of and the divide caused by nonreconciliation in South Africa was a divide between black and white South Africans. Today it is the divide between black and black, white and white, between rich and poor. According to him, the big issue in South Africa is now more one of class, than of race. Thirdly, he indicated that reconciliation in South Africa would not be achieved because of politicians, but 'despite' them. What is needed are people who and organisations that set their eyes on the next generation. Lastly, Aucamp indicated that the reconciliation agenda had been overshadowed in the past years by an ineffective and failing transformation agenda, leading to polarisation. The way the government has implemented transformation has left white people to feel marginalised and alienated. The government did not make sufficient attempts to co-opt them in issues such as land reform, social development and economic transformation. Minority racial and religious groups, in general, are disenchanted by the hegemony that government implementation of transformation enforces on society. Language rights, religious rights, cultural rights are increasingly coming under attack, especially within the education sector. National unity will not be realised if the right of diverse people is not respected. He concluded by saying that the GKSA is committed to reconciliation also through the preaching and enactment of the gospel of love in our lives. The message of reconciliation belongs to the core of the gospel. Aucamp stated that he believes that we have advanced a long way in South Africa and should never let the batten fall. We cannot become complacent, and we need to take our people with us.

The eleventh faith community to make a submission was the Apostolic Faith Mission (AFM). The AFM did make a submission to the TRC in 1997. Dr Isak Burger was unable to attend and asked Dr Frank Chikane, the president of the AFM International, to make the submission assisted by Pastor Daniel Andrews. Dr Chikane started his submission by stating that the AFM has been the best representation of what apartheid was all about as it consisted of separate churches for whites, Coloureds, Indians and Africans. However, in 1993, the AFM won the battle for unity when the black churches united and, in 1996, the black and the white AFM churches united. According to Chikane, reconciliation, healing and true history of the church cannot be emphasised enough. He said that this is important because it is necessary to revise history since it is often distorted, false and thus not an accurate reflection of what the church was all about. This revision was critical to him; one's history is critical because it has to do with one's identity. 
I Chronicle of the Re-enactment of the TRC's Faith Communities' Hearings I

Chikane also emphasised the importance of building bridges, communication, social responsibility and dealing with issues of poverty and other issues within the church. He remarked that a challenge to the AFM was its success in uniting at a national level, but not at a local level. To him, the church must address this discrepancy because if true unity fails in the church, it will be difficult to succeed in society. Chikane also referred to the AFM's commitment to the so-called decade of reconciliation (from 2002-2012), that focussed on these matters because of the realisation that it would not happen without active work towards it. He quoted the following from the master plan (2010) regarding this: "Having been an apartheid church, we see a church accessible to all people, celebrating our unity and Godgiven diversity; empowering our members for carrying and changing communities to the glory of God." In 2006, the AFM introduced a wellness plan to start to talk also about reconciliation beyond the AFM.

Chikane acknowledged that he could not say whether the AFM have defeated the demon of racism. Other remaining issues are class differentiation, the gender divide (though there has been progress made in this regard), social responsibility and prophetic witness. He indicated the importance of the development of the collective intervention in dealing with socio-economic challenges such as poverty, unemployment, education, skills development, the fight against crime and the promotion of social cohesion, as these are all critical to the church.

Andrews affirmed the importance of the church to take responsibility for the next generation. He then identified some lessons that he shared taken from Alan Boesak's Radical Reconciliation. In this book, Boesak reflects upon the Reitz hostel abuses at the University of the Free State. The first lesson from this incident is that one must see what is happening first through the eyes of those who suffer (whether victims of racism, sexism or even ageism or classism). Reconciliation does not begin with neutrality, but it begins with the intent, as the Belhar Confession puts it, to stand where God stands. Secondly, reconciliation is not possible unless the unequal power dynamics are addressed. Thirdly, reconciliation is never cheap but is a response by God's grace to the woundedness of others. Fourthly, there exists a place for rightful anger. Finally, genuine, radical reconciliation is perhaps the only way that people can walk away from the past as a family, forgiven, healed and restored.

At the conclusion of the first day of the consultation, Archbishop Tutu commented that he was very deeply moved by what he had experienced. He said that he was grateful, albeit surprised, at how the faith communities responded to the invitations to share in the fashion that they did during the day. He admitted that 
he thought it might merely be a kind of academic discussion that would ensue. However, given the honesty, passion and commitment reflected in the submissions made during the day, he again realised what an incredible privilege it had been to have been part of the TRC process with such gifted people. Tutu expressed his conviction that he had little doubt that God's Spirit was present at the consultation as at the original hearing in 1997, and that God was smiling on both occasions, smiling through the tears. God has again placed God's reputation in the hands of people and, therefore, if this country is going to get better, is going to be healed, then it is and will be up to us.

\section{Summary of Day Two}

The United Congregational Church of Southern Africa (UCCSA) that made a submission to the TRC in 1997 was the first faith community to make a submission on the second day of the consultation and the twelfth overall. In 1997, it was made by Rev (Prof) Steve de Gruchy (who has since tragically passed) and Rev Dr Des van der Water. At the consultation, Rev Thulani Ndlazi made the UCCSA submission. Ndlazi called his presentation, Being comfortable with the devil that we know, and began it with an excerpt from the 1997 UCCSA submission that stated:

... in many ways, the revelations to the Truth Commission have not come as
a shock to the ministers and members of the UCCSA. Our membership is
overwhelmingly made up of those who were victims of apartheid. We knew
all along that these things were happening, and this is why we said what we
said and did what we did. Nevertheless, we recognise the profound impact
the truth will have on the future generations of our country. There are sins to
be forgiven; wounds to be bound up; hatreds to be reconciled; buildings to
be rebuilt; peoples to be taught; leaders to be held accountable. This is the
task of the church of Jesus Christ. We are a small church, with few resources,
yet we acknowledge this calling, and commit ourselves to nurturing this
truth, healing the nation, and building a culture of tolerance and justice so
that our children and their children may never again suffer the evil, which
has so plagued our life in this nation.

Ndlazi then confessed that they did not honour their commitments to the best of their ability and, therefore, UCCSA has felt more comfortable with "the devil that it had known for many years under apartheid". He said that it had accepted a situation in which an abnormality was viewed and accepted normality; where it divided itself by race, it allowed language to become a political tool in the hands of government; it failed to (re)distribute land; it had lost much of the history and culture of its members; it was complicit in limiting religious expression in the country and its public educations system. Despite these failures, Ndlazi reaffirmed the UCCSA's commitment to proper health care: 


\section{Chronicle of the Re-enactment of the TRC's Faith Communities' Hearings I}

- the fight against sexual violence against women and children,

- efforts to deal with Afrophobia,

- reviewing of identity practices, seeking the celebration of all ethnic identities, cultural backgrounds and fighting for and promoting equal treatment of all languages,

- creating spaces for dialogue on the importance of being inclusive church communities,

- encouraging cross-cultural pulpit exchange,

- addressing violence and oppression,

- executing justice and righteousness,

- participation in and support of land struggles and progressive dialogue between landed and landless communities,

- bringing back a culture of religious expression and teachings in public schools, and

- promoting inter-faith tolerance.

The Evangelical Alliance of South Africa (TEASA) was the thirteenth faith community to make a submission at the consultation. Dr Moss Ntlha made its submission to the TRC in 1997, but since he could not be present at the consultation, his submission was read on his behalf by Dr Nadine Bowers du Toit.

The submission began by referring to the 1997-submission of TEASA to the TRC when it was said:

As representatives of the Evangelical Movement, we stand before the Commission and a nation in search of truth and reconciliation, with heads bowed in shame for the way our movement failed God and South Africans by not standing sufficiently with the poor and oppressed in the years of apartheid. This went against the biblical witness which we are committed to uphold. We are mindful of the fact that many South Africans might well be tempted to reject God on account of the way we represented Him. Instead of preaching Good News to the poor, we found it easier to conform to the ways of the wealthy and powerful. Instead of rejecting racism, we not only institutionalised it in our own churches, but we proclaimed the gospel as though the sin of racism and the violation of human rights did not matter to the God we serve.

The current submission then called for the acknowledgement that the government is ill-suited to deal with heart matters, what reconciliation is ultimately about, and that reconciliation was always going to be a peoples' mission because a government is restrained by political imperatives, such as amnesty without remorse; victims of human rights being limited to the few who appeared before the TRC; economic limitations in terms of how far reparations could hope to compensate people for the losses they suffered, to mention but a few. In this regard, TEASA set out to take responsibility and to move into action. Firstly, they created the TEASA Reparation Fund. The rationale behind this was that TEASA churches - many of whom were complicit in supporting apartheid - could find a way of at least taking ownership 
in the process of reconciliation and, in particular, in assisting victims of human rights violations. This assistance was mainly in the following forms: educational support for children of victims; medical assistance support; and income generation support. TEASA's experience in this regard was that there was enthusiasm amongst local churches to respond to the plight of victims of human rights abuses identified by the TRC. The challenge was, however, that white churches felt that they were asked by TEASA to buy into the narrative of the State that all whites were guilty of apartheid abuses. TEASA also participated in preparatory meetings to the Khulumani class action against US companies that benefited from apartheid, as this aspect of reparation was also important to them.

The second focus of TEASA was to address the churches'/denominations' reconciliation processes within. Significant efforts ensued towards structural unity within denominations - many of the latter were fragmented along apartheid lines. Sadly, however, reconciliation has not been achieved by the event of signing off on structural unity. The latter was in many ways the beginning of much labour and a struggle to sort through the complex web of apartheid relations and issues that, in the main, continue to fragment broader South African society.

The third focus of TEASA was the Reconciliation Summit, held in 2002, with its goal to explore whether or not there was life beyond confessions made at the TRC. According to TEASA, there was not a clear pastoral plan of how a different praxis could be imagined. The Conference accepted a ten-year commitment with each denomination deciding for itself how it would change its patterns, structures and systems to move away from the legacy of apartheid towards a more faithful Kingdom witness that could manifest unity and reconciliation. This fact was well accepted, but there appeared to be no energy left for vigorous engagement on these issues. However, while denominationally the reconciliation process seemed to face some structural challenges, on the ground, local churches and individuals embarked on reconciliation efforts of their own, leading to heart-warming stories of wealth redistributions, land redistribution and scholarships for the poor. New cross-cultural friendships have been and are being built among Christians and churches collaborating in joint mission projects in poor communities and believers continue to wrestle with what it means to be agents of reconciliation in their communities. The TEASA submission concluded with the statement that what was missing in the national discourse on reconciliation was the voice of the church.

Dr Bowers du Toit indicated that she would answer the questions by the panel of commissioners on her behalf as presenter of the TEASA submission. She referred to, amongst others, plans that were underway in 2016 to commemorate 
I Chronicle of the Re-enactment of the TRC's Faith Communities' Hearings I

the Soweto Uprising and to re-engage with that issue again. In terms of grave economic injustice, Dr Bowers du Toit indicated that she believes the answer lies at the grassroots and that the new challenge lies in local communities of the poor. They have a voice and need to speak out and together we need to speak of justice. According to her, in bridging that divide formal denominations and movements can assist in bringing people together. Dr Bowers du Toit further indicated that our hope lies in the youth and, therefore, we need to have more young people participating in these open and safe forums.

In her comments on the submission of TEASA, Commisioner Sooka indicated that the commissioners also have to acknowledge that they had made enormous mistakes. They, for example, confined the Reparation list initially to only people who appeared before the TRC. Only later on, in acknowledging that mistake in the 2003 report, it said that it had to be recognised that some survivors were not ready to speak about their experiences at that time, but it did not mean that they had not suffered the same violation. Sooka said the TRC further divided many communities. She recalled President Mandela saying, "Let's leave an opportunity for the South African corporations to come to the table around reparations. As long as you don't sue them, I will support your action." Khulumani lost the class action after many, many years in the United States, not because the action was wrong, but because at a policy level the United States government has impressed on the courts that they need to close the space for actions like that. However, the South African corporations did not come to the party and, Sooka said, the question needs to be discussed of how we can make up to the broader universe of victims out there.

The SACC was the only organisation that made a submission during the reenactment. Dr Brigalia Bam and Bishop Malusi Mpumlwana made the submission. Bam began the submission by commending the SACC for taking up the responsibility, given by President Mandela, for the recruitment of commissioners. Bam specifically mentioned Mandela's view of the need for the role the NGK had to play in the reconciliation process. He felt that to achieve reconciliation; the NGK needed to re-interpret its theology that had for long legitimised apartheid. Bam remembered Mandela saying this as he knew that the NGK had influence and credibility among many South Africans and the members of the NGK are people 'who fear God'.

According to Mpumlwana, the SACC exists amongst other things to lead common Christian action toward moral witness in South Africa, addressing issues of social and economic justice, national reconciliation, the integrity of creation, the eradication of poverty and contributing towards the empowerment of all those who are 
spiritually, socially and economically marginalised. He referred to the important remark made by Beyers Naudé in 1961 regarding the role of the church, when the latter declared that the Christian church must be an advocate for the poor, the oppressed, the hungry, the voiceless and the unjustly treated, whether they are black or white. To emphasise the role of the church further, Mpumlwana also referred to the famous letter that Desmond Tutu wrote to Prime Minister Vorster in May 1976 in which he said:

We all, black and white together, belong to South Africa, and blacks yield place to no-one in their passionate love for this our beloved country. We belong together. We will survive or be destroyed together. I write to you, Sir, because like you, I am deeply committed to real reconciliation with justice for all, and to peaceful change to a more just and open South African society in which the wonderful riches of wealth ... and wealth of our country will be shared more equitably.

Mpumlwana also referred extensively to Mandela's vision for the TRC, as his goal was to help South Africans of all races to open their hearts to one another, to appreciate their common destiny and to work together towards the reversal of the social and economic impact of the unreconciled apartheid past. Hence, Mandela said, "this Commission will emphasised not only to reconciliation but also to reconstruction and development." Mpumlwana observed the need to note that Mandela included social and economic justice in his understanding of reconciliation, but that the broader agenda for national reconciliation, mandating a social and economic agenda that would radically transform the fortunes of the black majority, somehow was side-tracked.

According to Mpumlwana, twenty years after 27 April 1994, we face a growing number of social and economic challenges. These challenges include a high unemployment rate (especially amongst the youth), increasing levels of desperation amongst the poor, rising discontent with the levels of inadequacy of service delivery (housing, sanitation, productive land, policing and crime prevention), the growing impunity of corruption, declining standards of education, declining levels of public morality and the dearth of voices of conscience and moral reason. In the face of this, the SACC has had to confront the challenges that have limited its effectiveness, including a changing funding environment, addressing the institutional gap, and attending to the decline, if not incoherence, of the witness programme of the church. National reconciliation cannot and shall never be a matter of engagement by single denominations, but always had and always will require collective ecumenical engagement and, in fact, the collective participation of all faith traditions. With this statement, the bishop reiterated the importance of the ecumenical and inter-faith movements and their ability to address reconciliation and justice issues. 
I Chronicle of the Re-enactment of the TRC's Faith Communities' Hearings I

The Muslim community was the fifteenth faith community to make a submission at the re-enactment. Imam Hassan Solomon, who unfortunately has since passed, made the original submission on behalf of the Muslim community and the Muslim Judicial Council (MJC) to the TRC in 1997. Mr Thandile Khona (President of the Muslim Youth Movement of South Africa) and Maulana Abdul Khaliq Allie (Secretary-General of the Muslim Traditional Council) made the submission at the re-enactment. Khona referred to the very slow and negligible progress towards reconciliation within the Muslim community. According to him, a culture of exclusion and marginalisation has taken root in Muslim communities - particularly, the exclusion and marginalisation of Africans and women. He regretted, for example, that the clerical institutions of the Muslim community were not at all representative of the demographics of the community. He believed that this made African Muslims in the house of Islam feel like stepchildren at best, and at worst, like slaves. In conclusion, Khona stressed that the Muslim community needed to begin with uncomfortable conversations amongst themselves en route to true reconciliation.

Maulana Abdul Khaliq Allie referred back to a section of the 1997-submission by Imam Solomon:

... On behalf of the Muslim Judicial Council, I would like to express our appreciation for this opportunity in the spirit of hope, to contribute to the truth of the past and peace and reconciliation for the future. History has planted Islam and Muslims in the Cape and South Africa now more than 315 years ago. Under conditions that were not unfamiliar to the majority of people in our country, Muslims were brought to South Africa either as captured freedom fighters against Dutch colonialism in the Far East; slaves to their European masters; or as indentured labourers. The sociopolitical relations of domination at the time ensured that Islam remained a subjugated religion of a minority, enjoying neither equality nor the right to free expression. As slaves and political exiles, besides the right to worship freely, they were denied the erection of places of worship and burial grounds.

Allie further indicated that Imam Hassan made a reference to the fact "that the $\mathrm{MJC}$ believes that it cannot divorce itself from the rest of the oppressed and those with the same ideals in the formation of a United Democratic Front to oppose the system of apartheid in South Africa." Allie, also spoke of the commitment of the Muslim community, and specifically the MJC, towards the TRC and to work together with the inter-faith community. He emphasised that we should appreciate that we have religious freedom in this country and, therefore, we need to allow ourselves an opportunity to pause and reflect and to listen to that history as well. 
Allie stressed that the Muslim community, as the MJC, believes that South Africans are waiting on the religious leaders today to lead them through the current crises, as they did in the years of the struggle. Allie then emphasised the need for true spirituality, truth and reconciliation to be placed at the centre together with restorative and social justice. As an example of this, Allie referred to the role they have played to nurture healthy and clear communication with all foreign nationals, to assist them in integrating into the richness of our communities. He further indicated that the Muslim community had established itself in all walks of life and are committed towards nation-building, cementing our democratic principles and continuously striving towards human dignity.

Khona responded to a remark made by Commissioner Piet Meiring. The latter commented on the wonderful work done by an organisation such as the Gift of the Givers, where the Muslim community is committing millions of Rands for example, to people in Gaza, Syria and to other places in the world where there are strife and suffering. To Khona, this remark raises a real concern for how we, in South Africa, live with ourselves when, right next to us, people are living in appalling conditions. He further referred to the challenges in South African society of inequality, the issue of the sharing of wealth whereto the Muslim community is not immune. In their answer to a question regarding the role of the youth of our country, the Muslim representatives emphasised the importance of the youth, the need for dialogue between the young people of different faiths and addressing challenges such as gangsterism, which is rife among the youth of all faiths in some communities.

The Hindu community was the sixteenth faith community to present a submission. Mr Ashwin Trikamjee, the President of the South African Hindu Maha Sabha, was present at the 1997 hearing and made the submission to the TRC at the time. At the re-enactment, Ms Ballen Gangen (South African Tamil Federation, SATF) on behalf of the President, Mr Karthi Moothsamy, who could not be present, made the submission together with Ms Nalini Gangen (Representative of the Maha Sabha). Mr Gangen started his submission with reference to the preamble of the constitution of the SATF, founded in 1968. It reads:

Recognising the necessity to protect and promote the Tamil language policy and traditions, and endorsing the need to do so in the manner consistent with the objectives of Constitution of the Republic of South Africa, including those relating to the advancement of human rights, the South African Tamil Federation representative body shall, in pursuing its objectives, operate in a non-racial, non-sexist and non-sectarian manner. 
I Chronicle of the Re-enactment of the TRC's Faith Communities' Hearings I

Mr Gangen then recalled the role of the Indian community in the struggle for human rights in South Africa. He referred to the recent strategic conference of the SATF, at the beginning of 2014, where issues concerning the youth and women were on the agenda. One of the resolutions accepted at that meeting was that all SATF structures would have a 50 per cent female representation and the intention to launch a youth forum.

Ms Gangen started her submission by referring to its logo and motto of the Maha Sabha, Vasudhaiva Kutumbakam, meaning 'the world is one family'. This motto resonates with the African concepts of Ubuntu and the Batho Pele (People First). The values on which Maha Sabha activities are based are selfless service, accountability, respect, fairness, social justice and unity. Gangen described in detail how the Indian community came to South Africa, the appalling circumstances they had to live and work in, the lack of education, et cetera. She also referred to the role the Indian community played in the fight against apartheid, for example, the iconic Mahatma Gandhi, Dr Yusuf Dadoo, Dr Monty Naicker and the role of the Natal and Transvaal Indian Congresses. She also reminded the consultation of two issues raised by Trikamjee in his 1997 submission, namely the celebration of religions and the issue of the non-recognition of Hindu marriages. Gangen further reflected on the recommendations made in 1997 and indicated that they did not do too badly in reaching these recommendations. She referred to the Maha Sabha's role in the Cape Town Interfaith Initiative to bridge the gap and jointly address issues such as road safety, its role in the 16 Days of Activism and initiatives concerning the challenges of gangsterism.

Finally, Gangen acknowledged that the Indian community still faces human rights issues and that they are often discriminated against when it comes to affirmative action. In terms of the future, she referred to the importance of the telling of the stories and future generations. In her conclusion, she proposed that faith communities, business and government work very closely for the next three years.

Chief Rabbi Dr Warren Goldstein, invited to make a submission on behalf of the South African Jewish community, could not attend due to the Festival of Tabernacles and therefore participated via a written submission. It was, however, not read due to time constraints. Mr Leonard Shapiro made a shortened submission from the South African Jewish community to the consultation, representing the South African Jewish Voices for a Just Peace (JVJP). Shapiro started his submission by indicating that the JVJP are a group of South African Jews who reject equating the religion and culture of Judaism with the political project of Zionism. They recognise that Palestinians 
live under a particularly brutal military occupation, based on a violation of their rights; they support the formation of a society based on equality and respect for human rights for all who live in what has now occupied Palestine and what can also be called Israel-Palestine. As such, this grave concern also played a central role in JVJP submission.

Having lived through one 'crime against humanity' - namely the system of apartheid - the members of the organisation stated that they could not turn a blind eye to the gross human rights abuses practised in the name of Jews against the Palestinian people. How could they as their rabbis have taught them that Judaism stands for moral values - such as justice, ethical behaviour, compassion and truth? Only a week ago, their submission recalled, on Yom Kippur, the Jewish Day of Atonement and Fast, Jews had asked for forgiveness for the times when they did not match up to this moral code. As South African Jews of conscience, the members of JVJP, therefore, call for an end to the occupation and for a new society to be built in Israel-Palestine, with equality for all people who live there, be they Jews, Muslims, Christians or atheists.

Shapiro reiterated that although they represent an alternative voice within the Jewish community, they are growing in numbers. Tutu thanked Mr Shapiro for JVJP support in distancing itself publicly from those who in the past has branded him a Nazi for his support of the Palestinian cause. Tutu said it deeply moved him that the JVJP at one instance complained about it to the Human Rights Commission. The submission of the Jewish community, the seventeenth submission, ended the submissions by faith communities at the consultation.

In conclusion after the submissions, Tutu as chair of the consultation reminded those present of what has happened in this country, the extraordinary people that God has given it and that we sometimes take this for granted. To illustrate this, he referred to Dr Brigalia Bam, who became the first chair of the South African Electoral Commission and how South Africans have taken for granted the exemplary way in which she fulfilled her mandate as chair to the extent that she and her colleagues on the Commission had been invited to assist in running free and fair elections elsewhere in the world. Tutu referred to Piet Meiring, who faced the wrath of his community at a time when it was not easy to befriend co-commissioner Tom Manthata, a survivor of apartheid torture. He also reminded the gathering of Mpumlwana, also tortured and who, together with his wife, was banned under apartheid laws. Tutu recalled how Mpumlwana, while he was banned, disobeyed his restriction orders to visit Tutu's offices and told him: "You know, Father, when 
I Chronicle of the Re-enactment of the TRC's Faith Communities' Hearings I

they tortured me, I always looked at them and said, by the way: 'These are God's children. And they need me to help them recover the humanity they are losing'."

Lastly, Tutu referred to Dr Frank Chikane, who was about to chair a session at the consultation on the way forward. Chikane was also detained and tortured. He should not have survived because his clothing had been impregnated with different toxins as he went through security at, then, Jan Smuts Airport. He was alive today because he went to the United States as his wife was there. Tutu admitted that some might have said that this was a coincidence and that one should not believe in coincidences. However, Chikane arrived at the teaching hospital where his wife was studying, and it so happened that there was a specialist in the toxin used. Therefore, when they diagnosed him, they discovered that Chikane's clothes were soaked in this specific toxin used. Chikane was alive today because of that 'coincidence' - the 'coincidence' of having gone to the USA at that time, to that specific place to be with his wife. Tutu concluded: "Therefore, sometimes, as we listen, I hope also we are aware not just of the words, but we are aware that we are where we are in this country because of some extraordinary human beings. And that God wants to use this country. God says, 'This is how you can be ...'”

\section{The way forward}

After Dr Chikane thanked the chair for his words and responded by stating that he, too, believes what happened to him was indeed a miracle, he started the session 'on the way forward' by thanking the Beyers Naudè Centre for Public Theology and the Desmond and Leah Tutu Legacy Foundation for initiating and organising the consultation. Admitting he was skeptical when he initially received the invitation, he was pleased that he did attend and participate. Chikane acknowledged that the inputs at the consultation were indeed extraordinary, much more than he ever thought they would be.

Dr Chikane started his take on a possible way forward by naming some of his key observations during the consultation: Firstly, he again realised that the founding act of the TRC was in itself a compromise. Secondly, how many of the submissions referred to an economic compromise and the short-changing of the poor. Thirdly, he realised that some TRC business had been left unfinished. Fourthly, a second conversion is needed for people to change the way they thought till now, and there is a need to understand the crisis we are facing differently. Lastly, there is a dire need for 'coordinated action'. We must ask ourselves, how are we going to work together as an interfaith community? 
The following is a summary of some of the suggestions from the floor that followed Chikane's invitation for contributions toward a way forward. Chikane's invitation read as follows: "As leaders and members of the communities of faith, we are conscious of unfinished business in the process of transformation in our nation. In particular we identify the following issues: ... And I leave it to you to fill in the list of issues to be completed..." They are:

- To establish a Truth and Reconciliation Continuation Group to attend to the 'Unfinished Business' after the TRC process. This group will coordinate the work of task groups focusing on issues identified during the consultation both to inform and equip the members of our communities about those issues and to engage with the government of our country (at national and regional level) on ways of addressing them.

- To request that our leaders at national and regional level engage with the Continuation Group in processes that will enable us all to work together for progress in these critical areas and so carry forward the transformation that will enable our nation to assume its rightful place in the family of nations.

- To emphasise that church leaders cannot go on with business as usual anymore. What we have been through during the TRC re-enactment consultation represents a Kairos moment. As such, we need a different kind of theology, one that can and will underpin the action. A theology that also flows from the grassroots experiences of young people, as we have heard here. A theology, deeply situated within the context of the long tradition of all liberation theologies. Whatever structure is decided upon, it needs to be constituted and re-energised by the post-TRC vision that has been discussed at this consultation.

- To acknowledge an urgency to act. We cannot afford a disjuncture between the mood of the marginalised and poor people in this country and the discussion of the last two days [i.e. during the consultation].

- To start teaching theologies that break down the walls of apartheid - in our churches, in the way we read the Bible together, also in our small groups. We recognise the need for change when we are changing, and we should challenge each other to change. If not, we cannot claim that we believe anything different. "As a white, English-speaking South African, I am tired of my community just side-stepping issues and pretending as if we had nothing to do with it then or now."

- To sit down with people in the informal settlements and with farmworkers. If we want to listen, we must listen [to] where our people are and where they suffer. Otherwise, we jeopardise our legitimacy and the integrity of this process.

- To give greater attention to the practicalities of how we transform relationships between those who give and those who receive. Are we listening to others, and how are we listening to others? From which perspective are we listening to others? We need educational programmes around restorative justice. We need major campaigns around non-racialism and the plight of our young people.

- To make a concerted effort to address the issue of the development of children even before they go to school. They need a firm foundation to build upon to ensure adequate literacy, numeracy, life skills and ethics. Perhaps we can work together to develop some 


\section{Chronicle of the Re-enactment of the TRC's Faith Communities' Hearings I}

material - basic and inexpensive - so that, twenty years from now, we have a generation of young people that have grown up with solid foundations.

- To listen to African Traditional Religions, that have not been represented at the consultation.

- To support religious structures that create safe spaces where intra-religious dialogue can take place.

- To develop leaders that people of faith can look up to and who can be the role models in and across the spectrum of our various inter-faith communities.

- To invest in the revival of the South African Council of Churches.

- To be creative and think anew about the structure of the TRC, as it is passed because we should not continue with it. We also need to embrace new themes and address new issues that were not present in 1997.

- To never forget issues around Gender Justice in this country.

- To set up structures that can assist us in restoring our dignity. For someone living in the township, the issues of justice and reconciliation are critical.

- To set up a follow-up programme for those young boys who were forced by circumstances to join the liberation struggles. After they were pardoned, was there a follow-up programme for them? If not, this should get attention.

- To set up spaces where the youth can tell their stories so that they can voice their anger, frustrations, hopes and dreams. We also need youth and, especially, youth leadership development programmes. The youth must also be empowered to help themselves.

- To assist young student leaders, that have begun with inter-faith conversations. We need knowledgeable people to assist them. We also need to include the youth in future conversations around the TRC and its legacy by physically inviting them to the table. The youth need to be taught what their elders have learned and how they can take it further.

- To create a new vision for our country, and in that vision solid, moral values must play a fundamental role.

- To help our teachers with their grappling issues. While work is done at a policy level, we are also working with the teachers of our country. They [are] calling out for support.

After thanking the gathering for the constructive inputs, Dr Chikane concluded the session with the following verbatim comments:

I realised yesterday that our own brothers and sisters in the faith communities need lots of support. They are still engaged in hard struggles to change systems. We need mutual support, and whatever mechanisms we set up should be able to deal with that.

I always say that, in terms of what we need to do, there are things that faith communities can do themselves and do not need government to do so. There are things we can do and must do; and, when we do them, it gives us credibility to engage government. If one does nothing, then one's credibility becomes questionable. Then there are, of course, things that government should do - and we must help them to do this. Having been there myself I realise that government also needs help. Government sometimes faces contradictions that make its work very difficult. Faith communities can assist it [in crossing] some of the bridges government needs to cross. The 
TRC had its function and has done it; they have done it brilliantly. They have given us the material; they assisted us [in coming and reflecting] again. Nevertheless, it is our responsibility as faith communities to act - and I am [hoping] that the relevant structures will assist us in this task.

I wish to end by sharing a recent engagement I had with Pieter Bezuidenhout, a chaplain in the South African Defence Force. He told me that he is doing research on the national service people who did national service between 1966 and 1989. I always wondered whether for our white brothers - especially those who were involved in the war and even the policemen I found at Union Buildings when I went there, young policemen - there ever was anybody who sat down with them and actually discussed what happened to them. Pieter told me that in discussions he had with them, he sensed a lot of hurt and pain. For them, the TRC happened at a moment that most of them were not ready for it, so they did not actually come forward. Some would be amongst those who rejected the TRC and its work. He even took me with him to some of the young men who felt that they wanted to make their own confessions, which they never had time to do. In addition, some of them remembered the June $16^{\text {th }}$ kids and asked me [whether] I could create an opportunity for them to engage with the June $16^{\text {th }}$ kids. I said I would talk to the leadership in Soweto and to the leadership of the NGK as this should be a faith-based rather than political engagement. Therefore, our job is not finished. South Africa has a long way to go to deal with the pain of the past. Moreover, it is not only a black thing; it is a black/white thing.

Chikane then emphasised the need to collect all the input and statements made at the consultation, to compile it and to make it available to all the faith communities. He suggested that the whole compilation also be sent to the SACC, asking them to put it on their agenda, to take the process further and in doing so to take other faith communities with them in the process.

\section{Reflections on the process}

The reflection session was a significant session during the re-enactment consultation. It offered input on the process from local and international scholars on reconciliation from diverse contexts. All but one of the reflections of these invited participants - that of Prof Jaap Durand - appear in full elsewhere in this publication. The scholars who gave reflective input were:

Prof Jaap Durand, is a well-known public thinker, theologian and emeritus professor of Systematic Theology at the University of the Western Cape. He shaped the theological thought of a generation of URCSA theologians in South Africa. As a theologian and later Deputy Vice-Chancellor of the University of the Western Cape, Prof Durand was also a [staunch] opponent of apartheid during its most turbulent years. Durand's short reflection is quoted in full here: 
I Chronicle of the Re-enactment of the TRC's Faith Communities' Hearings I

Thank you very much for this opportunity. I want to say that I believe that God is a God of second chances. When I say it, I believe it with all my heart. If I did not believe it, if I did not believe it with all my being, I would have given up hope for South Africa. I would have given up hope for us. How many opportunities ... how many opportunities have we squandered to embrace each other in the name of God? How many opportunities we have squandered to thank God for the patience towards us by our acts of reconciliation. We squandered it with regard to justice, to unity, by not reaching out to each other. Is it reasonable that we do not believe what we profess to believe? Of all countries that are so manifestly religious, we would have expected the direct opposite. However, is that perhaps our problem? That we are too religious? Too self-satisfied in our own religiosity that we think we can depend on our religiosity to pull us through instead of seriously looking at God? The God of our belief; the God who is willing to give us second chances, while we, on the other hand, begrudge the other one chance of reconciliation.

In a time of crisis Karl Barth, the great Karl Barth, spoke of 'Religion ist Unglaube' - religion as unbelief. Write this on a piece of paper and keep it on your breast next to your heart [as] Blaise Pascal did. In 1990, I addressed a group of churches at my old stamping ground as minister of KwaZakele and New Brighton. On that occasion, I referred to two Latin words for the future: futurum and adventus. The second word refers to the coming of somebody. In addition, this is a message for them in 1990, in 1994 and today. The future - the adventus means the coming of God, even better still: God is our future. This is God's promise. Nevertheless, it must be clear to all of us that there are conditions attached to God's promises. God can even come to us in his anger if we harden our hearts against his clear message to that he expects us to travel the road of reconciliation, justice and unity in South Africa. That is precisely the road that God has prepared for us. Do we want to deny that? If we do not travel that road, I fear the adventus of God. My dear sisters and brothers, I still believe - and I keep on believing - that God is a God of second chances. May God forbid that we squander what God is willing to give us yet again.

Prof Durand's statement was followed by ones by:

Imam Rashied Omar is a well-known Western Cape research scholar of Islamic Studies and Peace Building at the Kroc Institute for International Peace Studies at the University of Notre Dame in the USA. He serves as co-ordinating Imam at the Claremont Main Road Mosque in Cape Town and is a board member at the Institute for the Healing of Memories.

Prof Eddy van der Borght is a theologian from the Vrije Universiteit, Amsterdam. He holds the Desmond Tutu Chair at that University and has played a major role in setting up funding research cooperation between South Africa and the Netherlands, specifically on topics related to transformation. Reconciliation is one of the central topics of this research. 
Prof Nico Koopman serves as Vice-Rector: Social Impact, Transformation and Personnel of the Stellenbosch University. During the consultation, he was the Dean of the Faculty of Theology where he was also a professor of systematic theology. Koopman has played a key role in the transformation of the Faculty of Theology. His theological work strongly focuses on issues of reconciliation, human dignity and hope.

Dr Vicentia Kgabe, Rector of the College of Transfiguration in Grahamstown. She holds a PhD in Practical Theology and also is an alumna of the University of Pretoria's Gordon Institute of Business Science leadership programme.

Dr Deon Snyman from the Foundation for Church-led Restitution concluded this session with a short introduction on church-led restitution. He recalled how the Foundation was established in 2003 in response to the South African churches' lack of response to the restitution recommendations of the TRC. At its inception, the organisation set itself the aim of becoming a catalyst for restitution that would lead to healing in South Africa. The organisation's current strategy is the development and facilitation of community-led restitution programmes, piloted over the past six years in the town of Worcester. In 2012, the Foundation for Church-led Restitution initiated a virtual discussion on the role of restitution in South Africa. As part of this discussion, South African theologians and church leaders were invited to write - in less than three paragraphs! - a short piece on the theological basis for restitution within the South African context. Twenty-four theologians and church leaders accepted the challenge and their contributions were published on the organisation's website. The Foundation for Church-led Restitution used the opportunity of the re-enacted Faith Hearings of the TRC to submit the different contributions to the gathering in the hope that they will serve as a catalyst for the starting of a debate within the South African church on the theological rationale for restitution within the South African context. With this aim in mind, Dr Snyman presented a copy of these contributions to Tutu, as chair.

\section{Concluding remarks by Archbishop Tutu}

In his conclusion, Tutu referred to the TRC as 'a very broken instrument', but one that God, nevertheless, used. In Tutu's words:

God blessed us ... God blessed us in this country. God is blessing us. We ought to be taking off our shoes because this is holy ground. During the last two days, we have spoken about many awful things, and they are true. But, you know, we haven't mentioned some of the positive processes that developed since the TRC, such as the Foundation for Church-led Restitution 


\section{of Deon Snyman, the Transformation Charter accepted in Franschhoek where farm owners have worked out an agreement on profit sharing with farmworkers and where the children of the farmworkers go to the best schools.}

With above examples in mind, Tutu urged the people not to leave the country as he believes that God chose it. Therefore, South Africa is a country that is meant to show the world how to be the family of God. He stated that as delegates leave the consultation, they do so, knowing that they have all been sinners. However, Tutu reminded delegates, they should also leave knowing that they are sinners who are repenting and that God is going to be blessing them. They will get angry with each other, yes, because sometimes one cannot control all things. They come from the pit of one's stomach. "But, you know what? If we fail in South Africa, if we fail - and I am not trying to be arrogant - if we fail, there is very little chance for the rest of God's world ... Very little chance."

\section{Afterword: Actions following the consultation}

During the TRC re-enactment, some decisions were taken on the way forward after the consultation. It was decided to collect all the input and statements made during the consultation to present it to churches and faith communities. It was also decided to send a report on the proceedings and the submissions to the SACC. The SACC was requested to take responsibility for all that has come from this consultation. They were also asked to put it on their agenda and to make sure they take the other faith communities with them in the process. The faith communities were also requested to report to the SACC in three months' time and, lastly, the Beyers Naudé Centre for Public Theology and the Desmond and Leah Tutu Legacy Foundation that organised the event, indicated that they would play a role, if needed, to monitor the process. Bishop Mpumlwana accepted the responsibility on behalf of the SACC. He indicated that they would want to occasion a public report and, therefore, it is essential to receive feedback from all the faith communities.

In 2015 a follow-up workshop was presented, under the auspices of the Beyers Naudé Centre to reflect on the recommendations made by the re-enactment consultation of the TRC Faith Communities' Hearings. The participants in the workshop were people that represented the diversity of the country as well as several young people. During the initial symposium that led to the re-enactment and as a direct consequence of the consultation, the Beyers Naudé Centre for Public theology also hosted a workshop on conscription into the South African 
Defence Force on the 18 to 19 January 2016. Christo Thesnaar, Theresa Edlmann and Wilhelm Verwoerd convened the workshop. This meeting aimed to create a dynamic, supportive and participative space in which Master's and PhD students recently and currently engaged in research relating to conscription into the SADF could share their work and receive feedback and peer support from other researchers. Participants from a wide variety of disciplines attended the workshop. The input and discussions during this workshop were profound, honest, frank and meaningful. It again emphasised the impact conscription still have on lives currently, years after the end of apartheid and the vulnerability of this particular group in our society. It also emphasised the necessity for continued engagement with this group.

\section{General concluding remarks}

There are many reasons to criticise the way the TRC was established, the functioning thereof, or the work done by it. However, the TRC Report did provide all South Africans, including government, non-governmental organisations and faith communities with clear recommendations to take forward, address and implement. Unfortunately, somehow, over the years following the TRC hearings, it seems we have all dropped the baton passed on to us by the Commission. What we have witnessed from the faith communities during the consultation was that they were no exception and, therefore, this space was created to remind them of the commitments they made to reconciliation and healing during the TRC Faith Hearing in 1997. However, it also provided an opportunity to recommit to reconciliation and healing within our current context and in the future. With this in mind, the consultation brought the faith communities together again to give them another chance to pick up the baton. Everyone present bears witness to what happened during the consultation and, therefore, are responsible and accountable to their faith communities and to broader society to work actively towards reconciliation and healing.

The SACC'S offer to take the process further is greatly appreciated. However, we need to remember that we are part of the SACC and, therefore, co-responsible in this regard. We are co-responsible to make sure that what was talked about, discussed, decided and proposed should materialise. We will held accountable if we do not listen to the theologies where people are living, functioning and socialising. We further need to learn the language of reconciliation to understand it if we want to contribute to reconciliation and healing in our country. 
I Chronicle of the Re-enactment of the TRC's Faith Communities' Hearings I

As time passed since the consultation and it became increasingly clear that very little of the recommendations of the TRC have materialised into structures and action. It was also clear that new energy needs to be generated to ensure that the 'second chance' referred to by Jaap Durand materialises. It, furthermore, became apparent from the outcome of the consultation and voices from the next generation that the concept reconciliation has become more and more contested and should always include the challenge of justice (with regard to land, economic, social and gender justice). As the Beyers Naudé Centre for public theology (BNC) was part of organising the consultation, and therefore co-responsible for the outcomes of the consultation we realized that there was a real need to develop a more formal structure to assist in the process of continues engagement with the outcomes of the consultation and to create a space that can contribute towards reconciliation and justice within our country. With this in mind a workshop was organised to gather partners from faith communities and especially members of the younger generation into a process of consultation and consensus seeking in terms of what a constructive way forward could entail. One outcome of the consultation was the establishment a Unit for Reconciliation and Justice Unit (URJ), within the BNC. The Unit was also inspired by Dr Beyers Naudé's example of responsible citizenship; his involvement in society on the basis of his Christian theological convictions; his courageous quest for justice and a life of dignity for all members of society; his humble and gentle efforts to promote a culture of dialogue and deliberation; and his commitment to the cause of the poor, the destitute, the wronged and the marginalised. Currently, the URJ are organising workshops, seminars, and developing publications in the field of reconciliation and justice.

In conclusion, let us recall the remark made by Tutu when he said he totally underestimated the need for the faith communities to have a space to talk and to share. As organisers of the event, we were all extremely grateful, if not amazed, that (especially) the churches, but also other faith communities took their participation in the consultation so seriously and shared in such honest and profound ways. We were also humbled by the number of messages from churches and faith communities expressing their appreciation for the consultation and committing themselves to the process of reconciliation in South Africa. 